\title{
Do Payout Policies and Channel Preferences of Banking Industries Shift during the Tranquil Periods? Evidence from Emerging Market
}

\section{Sagheer Muhammad*, Sehrish Mubeen** and Mah Noor Shahzadi***}

\begin{abstract}
This study investigates whether the dividend policy (the decision to distribute funds, and the distribution channel preferences) of the banking sector of Pakistan is affected during any periods of domestic and global financial crisis. Using a sample of publically listed commercial banks, between the periods of 2002 till 2015, this research document that, unlike other countries, the banks in Pakistan fail to indicate a decline in the level of funds that are distributed to the investors. Even though the importance of the other means of distribution has increased over time, a major portion of the total payout is still covered by the cash dividends. Moreover, the results of the multinomial logit model, demonstrate that the payout policy of the commercial banks listed on the PSX, is not influenced by the global financial crisis. Furthermore, the analysis reveals that more liquid, profitable, and growth oriented banks have a higher tendency to pay dividends, than the other banks that do not fall in this category. The empirical results also indicate that the signaling hypothesis is a relevant economic phenomenon. These findings provide insights to different stakeholders in developing the relevant policies needed to cope up with crisis situations, such as the current ongoing Coronavirus pandemic.
\end{abstract}

Keywords: Payout policy, payout channel preferences, financial crises, Multinomial Logit Mode.

JEL Classification: G35, G32, G30.

\section{Introduction}

Since the past few centuries, financial institutions, especially banks, are considered to be the heart of any country's economic system. In

\footnotetext{
${ }^{*}$ Lecturer, Department of Management Sciences, University of Gujrat, Gujrat, Pakistan.

${ }^{* *}$ MPhil Scholar, Department of Management Sciences, University of Gujrat, Gujrat, Pakistan.

${ }^{* * *}$ MPhil Scholar, Department of Management Sciences, University of Gujrat, Gujrat, Pakistan.
} 
emerging and transitioning economies, the position of a well- performing banking region has been recognized as the engine of economic development and growth (La Porta, Lopez-de-Silanes, Shleifer, \& Vishny, 2002). The overall performance of a bank is largely dependent upon the key strategic decisions that are made by its corporate managers. Among all the strategic decision made at the board level, designing the optimal dividend policy still remains a vital and challenging task for corporate managers. The puzzling decisions about the distribution of funds, become even more complex in situations of financial turmoil. As the ultimate goal of the financial managers is to make corporate decisions that lead towards a higher share price, an optimal dividend policy has always fascinated researchers, because it is known to be one of the fundamental determinants of shareholders wealth maximization. Seneque (1978) defined dividends as, the proportion of the profit earned by a company, which is given to its shareholders. Whereas, the payout policy is said to be the strategy that the managers pursue, while making payout decisions. In general, the payout policies consist of the payout levels, and the payout channels through which the firm returns capital to its shareholders (Samet \& Jarboui, 2017). The presence of different costs, such as the flotation cost, interest rates, absent binding covenants, and time restrictions, make the capital markets more complex. This, in turn, forces firms to finance various investment opportunities that pop up in the market, only through the internal sources of the funds (mostly retained earnings) (DeAngelo \& DeAngelo, 1990; Donaldson, 1961; Myers \& Majluf, 1984). Under these conditions, the management has to make serious efforts, while deciding what proportion of the earnings should be distributed as dividends, and what should be retained in the business, for the forthcoming perspective projects (Denis \& Osobov, 2008; Van Horne \& McDonald, 1971).

Recognizing that dividends play a critical role in the banking sector, Floyed, Li and Skinner (2015) state that "by paying and increasing dividends, bank managers signal to external constituents, including depositors and short-term creditors, that they are confident about bank solvency'. For investors, this means that banks can be considered reliable dividend payers, and are likely to continue to increase their dividends over time. But, it is noteworthy that bank shareholders are not just receiving a direct deposit after every quarter, rather, they are receiving a message. In the wake of a crisis situation, investors' residual skepticism about financial firms' health only serves as a means to make dividends more important for banks- to the extent that it often surprises the researchers. Hence, it can be concurred that dividends are considered to be pervasive for banks, in a context that does not apply to other types of firms (Floyd et al., 2015). 


\section{the Tranquil Periods?}

There are numerous theoretical models, and empirical studies available in the literature, which are associated with the dividend conundrum. Specifically, two schools of thought (dividend irrelevance and dividend relevance) are noteworthy, regarding the change in a firm's value, caused by its dividend policy. Accordingly, in this context, the dividend irrelevance theory states that, under a fully competitive market, the only element that can affect a firm's value is an investment decision, while the dividend decision remains unrelated to this resolute (Miller \& Modigliani, 1961). On the other hand, the dividend relevance theory provides an alternative explanation, and demonstrates that a firm's dividend related decisions can significantly affect its market and organizational value. This theory is based on a rationale that there is a presence of numerous factors (taxes, agency cost, transaction cost, agency cost, flotation cost, and behavioral factors) that contribute towards making capital markets imperfect. Furthermore, many researchers in the extant literatures have proposed several other hypotheses (signaling hypothesis, agency theory, tax preference hypothesis, and clientele effect hypotheses), which support the rationale of the relevance theory (Gordon, 1963; Lintner, 1962; Walter, 1963). However, even after an extensive amount of research done by researchers, the dividend behavior is still a confusing discipline for theorists and researchers. Black (1976) famously quoted 'The harder we look at the dividend picture, the more it seems like a puzzle, with pieces that just do not fit together' (Bushra, 2012).

The economic crisis of 2007-2009 was driven by the major banks' weakness in the US financial market, which eventually turned into one of the most impactful global financial crisis of today's day and age. According to the World Bank report of 2009, the economies of developing countries, including Pakistan, were highly affected by this crisis. Despite a major drop of $17 \%$ in the KSE index, the commercial banks in Pakistan were among those that confronted the detrimental impact of the financial crisis with a head on approach. Albeit none of the banks collapsed due to the crisis, it still left considerable and significant impact on the financial performance, patterns, and operational policies of the banks (Nazir, Abdullah, \& Nawaz, 2012). Meanwhile, in the wake of the financial crisis, the Basel committee developed a new reform (Basel III). This reform incorporated more conservative and challenging capital requirements for the banks, forcing them to cut down the dividends, and plow back their earnings (Abreu \& Gulamhussen, 2013).

Following the financial distress, and the forthcoming shifts in the regulatory reforms (Basel III), a fundamental question had been raised: 
Does the payout policy of commercial banks tend to change, following a financial collapse? Hence, in this research, we aim to study commercial banks rather than financial institutions, because banks are essential for the survival of the economic system, their payout policy receives significant interest during the crisis period, and they are more homogenous in nature, as compared to any other financial institution.

For this study, we have analyzed the dividend paying behavior of the banks listed in Pakistan, over a period spanning from the year 2002-2015, and have emphasized on two key aspects. Firstly, we have examined the decision of the bank to pay dividends. Secondly, we have analyzed the payout channel preferences i.e. cash dividends, stock dividend, or mixed dividend of the banks during the time of the financial meltdown.

After analyzing many different settings, we have come to the conclusion, that most of the banks in Pakistan use dividends, as a medium of distributing profits to their shareholders. Moreover, the results of the multinomial logit model demonstrate that, the payout policy of commercial banks that are listed on the PSX is not influenced by the global financial crisis. Whereas, the results regarding the changes in the channel choices suggest that the cash dividend gets an eminent status after a financial crisis has passed. It also reveals that liquid, profitable, and growing banks have a greater tendency to pay out the dividends to their investors. In short, the evidence presented above is consistent with the idea that, banks use dividends to signal their financial strength in the market.

This study complements the growing literature that is based on the pay-out policies that are used by the banks in many ways; firstly, even though an ample amount of studies exist on the determinants and effects of the payout policy (Ahmad \& Javid, 2009; Bushra \& Mirza, 2015; Khan, 2012; Mbulawa, Okurut, Ntsosa, \& Sinha, 2020; Roomi, Chaudhry, \& Azeem, 2011), the extent of our knowledge tells us that this is the first study of its kind which investigates the choice of the earning distribution channel (cash dividends, stock dividend or mixed dividend of) by the commercial banks in Pakistan. Secondly, the financial crisis and the payout policy are always presented as two separate topics in literature, and no study has been done based on the association between them. To fill in this gap, the present study thoroughly addresses the dividend policy of the banks during the global financial crisis of 2007-2009, and provides a unique setting for the study pertaining to the decisions related to corporate finance. Furthermore, most of the studies available on this topic are carried out in developed countries; hence, we investigate this particular phenomenon in the emerging market of 

the Tranquil Periods?

Pakistan, which is assumed to possess different characteristics. Finally, recent studies available in the literature mostly concentrate on the dividend policy of the nonfinancial sector. Therefore, this study tries to analyze the payout policy of the financial sector, with a focus, specifically, on the commercial banks.

Meanwhile, the findings of the current study will shed critical light on the corporate finance theories, and will also help investors to make investments in firms whose payout policy matches their style. Additionally, it will also work as a guide for corporations that, by developing their payout policy, under the light of the evidence presented in this study, can increase a firm's value and reduce conflicts between the management and the shareholders.

The remainder of the paper is organized as follows. Section II reviews the related literature, while section III provide the complete detail about the sample and methodology. Section IV discusses the results of the empirical analysis, and finally, the concluding remarks are present in section V.

\section{Literature Review}

An important question that is often put up pertains to why firms pay dividends, and what are the main factors that can influence a firm's dividend decision? The majority of the extant theoretical and empirical literature is available on the dividend policy and announcement effects. As per Miller and Modigliani's (1961) Dividend Irrelevance Theorem, given an efficient market, ideally dividend decisions should be a matter of indifference to the shareholders and firms. Black, Fisher, and Scholes (1974) also provide evidence in support of the dividend irrelevance hypothesis. Specifically, by examining the stock returns, and the dividend yield relationship, they showed that the stock price does not affect a firm's dividend policy. On the other hand, a counter-argument also exists with regards to the relationship between the dividend policy, and the firm's value. At a more theoretical level, an extensive amount of literature focuses on how the existence of market inefficiencies, investor irrationality, and limits of arbitrage, may render the dividend policy irrelevant to a firm's valuation. Apart from the evidence presented above, DeAngelo and DeAngelo (2006) provide a new explanation of the payout policy. Their results show, that a firm's decision to distribute funds is dependent on the Life-Cycle theory. Based on this premise, a mature firm distributes it's earning to the shareholders, in the form of dividends, than a growth one, 
because it has fewer investment opportunities to finance. Lintner's (1956) partial adjustment model also provides a foundation for the so-called signaling hypothesis. The theory assumes that managers use dividends, deliberately, to convey a signal about the firm's future performance. Therefore, when firms set a target payout ratio, the shifts in earnings translate into the shifts in the payout policy. Accordingly, many interpretations of why dividends exist, are rested on the agency theory, as coined in by Jensen and Meckling (1976). Under this theory, dividends reduce the level of cash that a can firm hold, which in turn forces the capital market to acquire external funds, when trying to finance new investment opportunities. This induces strict external monitoring, thus, reducing the problems with the agency. Meanwhile, the clientele effect, or the tax hypothesis provides the basis for the assumption that, the dividend policy is relevant, or has an effect on the firm's value. The theory asserts that, different dividend policies attract investors from having different preferences. Moreover, because of the tax disadvantage associated with dividends, firms frequently use a conservative payout policy (Elton \& Gruber, 1970).

As far as the distribution channels are concerned, it is said that cash dividends are inductive of the future financial performance of the firm, which increases a firm's ability to have easier access to funds from the external market. Moreover, it also argues that cash dividends are a sign of treasury for shareholders, and the retention of earnings is not appreciated by the investors. Lee and Xiao (2004), and Chen, Jian, and Xu (2009) suggest that the cash dividends are important for firms that intend to acquire funds by equity issuance, after the IPO. Taking investor irrationality into consideration, it is claimed that investors favor cash dividends, over others. The theory is based on the idea that, for some investors, self-control is assumed to be a major trigger of choosing cash dividends, because they wish to avoid regret. Specifically, when investors receive cash dividends, they can consume them, and the utility they gain in this case, will be more than the utility they will get through future capital gains that are uncertain (Shefrin \& Statmen, 1984). Like cash dividends, stock dividends, and mixed dividends are known to be important channels that a firm uses, in order to distribute their earnings to shareholders. David and Ginlinger (2016) demonstrate that firms prefer stock dividends, in the time of an economic setback, in order to maintain confidence in the market. Tax based explanation suggests that both firms and investors prefer a payout method, which yields the most favorable text treatment. Wang, Manry, and Wandler (2011) highlight taxes as another reason why firms prefer stock dividends, over cash dividends. They further argue that the tax on cash dividends is 

the Tranquil Periods?

higher than the tax on capital gain, thus, investors choose to receive shares. Consistent with the dividend clientele effect, firms alter their payout policies, based on changes in the tax system. This is because the incentives of the shareholders and managers are highly affected by the new tax reforms (Korkeamaki, Liljeblom, \& Pasternack, 2010). David and Ginglinger (2016), after linking the payout channel choices, with the agency theory, illustrate that firms with major institutional investors are more likely to pay out the stock dividends in downturns of an economy. They believe that by doing so, these firms can increase the ownership of the investors, with long term horizons, who are not affected by the short term fluctuation in the share prices. The agency theory suggests that, investors in growing firms that establish effective governance mechanisms, are ready to accept a large amount of retention, and a lower level of cash dividends (Chen, Chadam, Jiang, \& Zheng, 2008). After analyzing the possible impact of the share repurchases on a firm's total payout, Andres, Doumet, Fernau, and Theissen (2015) suggest that buyback is not a perfect substitute for dividends, and the dividends are assumed to be stickier then the total payouts.

Extensive research has shown that the dividend decision is related to certain characteristics that a firm possesses. It is documented that a firm's profitability influences the dividend policy (Akbar \& Baig, 2010; Bushra \& Mirza, 2015; Fahim, Khurshid \& Tahir., 2015; Kouser, Luqman, Yaseen, \& Azeem, 2015; Malkawi, 2008). According to Carroll (1995), the positive association between earnings and payout is discernable. That is to say that, as earnings increase, the dividend payments become higher, while, decreases in the earnings, lead towards dividend cuts. When focusing on the firm size and liquidity, it is indicated that both these variables are positively related to the dividend policy. Lee, Singal, and Kang (2013) reveal that, because of the easy access to external finance, and also due to the lower growth opportunities, larger firms are more inclined towards paying out the dividends to their stakeholders. The likelihood of paying cash dividend is higher for companies that hold a large sum of money, as compared those that have just enough money to fulfill their working capital requirements (Ho, 2003). Moreover, it is also stated that leveraging negatively tends to have an adverse effect on the payout policy of a firm. In their paper, Agrawal and Jayaraman (1994) describe that leveraged firms prefer to maintain internal funds, in order to make timely payments to creditors, rather than distributing the payments to their shareholders. Likewise, growing firms are less likely to pay out the dividends to their shareholders (Trojanowski \& Reneeboog, 2005). This empirical finding is explained by the observation that the probability of dividend omission is greater for firms having a higher growth potential, 
because they choose to keep cash in order to finance any additional investment opportunities in the future.

Several empirical studies have highlighted the possible shifts in the corporate payout policy, caused by the recent global financial crisis. This global financial crisis had been considered as an exogenous shock to the companies, which was assumed to have affected the dividend policy as well (Basse, 2019; Hilliard, Jahera, \& Zhang, 2019; Mbulawa et al., 2020; Tran, Alphonse, \& Nguyen, 2017). Moreover, a large number of financial institutions collapsed during the years spanning from 2007 to 2009. This meant that the banking institutions paid heavy penalties in terms of the adverse effects that they encountered. Using the Logistic Regression Model, Hauser (2013) showed that in order to avoid financial risks, in the midst of financial meltdowns, firms prefer to increase their cash ratio, rather than maintaining the dividend policy. Likewise, opposite to dividend signaling or dividend smoothing hypothesis, insurance companies in Europe cut down the dividend payments, in order to preserve their capital, and to comply with the regulatory standards when experiencing a severe liquidity crisis (Reddemann, Basse, \& Schulenburg, 2010). Contrary to the facts presented above, Floyd, Li, and Skinner (2015) provided evidence regarding the observation that the declining propensity to distribute funds is not evident in the case of banks, especially during periods of tranquility. The plausible explanation of the reluctance to cut dividends is that, dividends are used by banks to signal their financial strength in the market. Recently, a study was organized to carry out an empirical analysis of the dividend smoothing behavior of the firms that are listed in Oman. When testing this theory with Lintner's (1956) Partial adjustment model, the findings revealed that the financial crisis does not significantly influence the dividend policy, and firms are less likely to cut dividends, even after a major setback, which comes in the form of a crisis (Al-Malkawi, Bhatti, \& Magableh, 2014). Similarly, after analyzing the Italian insurance sector, Reddemann et al. (2010) highlighted, that the act of dividend omission is a less attractive, and relatively less preferred measure for the firm. This is primarily because it stems the apprehension that, the probable dividend cuts could be interpreted by the investors in a negative manner.

\section{Data Description and Methodology}

\subsection{Sample and Data collection:}

In order to carry out an effective empirical analysis, our sample covers the banks that are listed in Pakistan Stock Exchange, over the period 

the Tranquil Periods?

that spans between the years 2002-2015. Moreover, we have focused on commercial banks, because they are important in their own right, and also, with a market capitalization of 1.2 trillion PKR, they are considered to be the hub of the financial services sector in Pakistan. Inclusion in the sample required that the data related to the variables must be available during the time period between the years 2002-2015. Furthermore, as this study is quantitative in nature, secondary data is utilized, for the purpose of a deeper understanding and investigation of the intricacies involved in this context. The data is drawn from two main sources. Our first, and primary source is the financial reports, while any additional data has been acquired from the analysis of the financial statements, as published by SBP.

\subsection{Econometric Model}

In order to examine the impact, of the recent financial crisis, on the payout policies (Decision to pay, and Payout Channel preferences) of banks, we have used the Multinomial Logit Model (MNL). The reasons for selecting a Multinomial logit model, over other models are twofold. Firstly, it handles all types of non-linear relationships. Secondly, it is often preferred by the researchers, as compared to the more sophisticated probit (Dow \& Endersby, 2004), which is likely to experience a weak identification problem in the model. Following the work of Reneeboog (2005) and, Geailer and Reeneboog (2016), the dependent variable in our study is computing out to be the payout policy, which can be presented in 4 forms; no dividend, cash dividends, stock dividend, and mixed dividend. Each of these outcomes is coded as $0,1,2$, and 3, respectively. Along with this, the total payout ratio (total payout scaled by net income), and the dividend payout ratio (cash dividends scaled by net income) are have also been utilized, in order to observe the trend and preferred mode of distribution.

The major explanatory variable in this study, is the recent global financial crisis (2007-2010). Therefore, to take into consideration the effects of the financial crisis, on the payout policy of the banks listed in Pakistan, we have further sub-divided our sample into three periods; 2002-2006 (precrisis phase), 2007-2010 (crisis phase), and 2011-2015 (post-crisis phase). We have then constructed a series of dummy variables, in order to identify whether a particular observation falls into a particular sub-period.

Furthermore, a set of firm specific characteristics, which are controlled in this study, comprise of certain variables that will be used to deduce the results that are required. One of the prime variables include the firm size (SIZE). The firm size is defined as a natural logarithm of total 
assets, which is expected to have a positive effect on the dividend payouts, as large diversified firms have more stable cash flows. It is noteworthy that such firms are likely to have low probability of bankruptcy, which puts them in a better position to distribute funds (Asghar, Shah, Hamid, \& Suleman, 2011; Shepherd \& Scott, 1975). Contrary to the positive effects, by investigating the listed companies in Pakistan, Bushra and Mirza (2015) argued that larger firms are more likely to retain cash, in order to meet their debt obligations. Similarly, the variable of profitability is also taken as an independent variable, and is measured through the return on assets. The return on assets is also expected to be positively related with the dividend payout, which indicates that more profitable firms tend to distribute more dividends (Ahmad \& Javid, 2008; Ben Naceur, Goaied, \& Belanes, 2006; Tahir \& Mushtaq, 2016). Moving further in the understanding of this context, it is observed that organizations with more investment opportunities tend to pay fewer dividends. Moreover, in order to avoid the external financing cost, growing firms prefer internal financing, and therefore, the variable of investment opportunities carries an inverse relationship with the pay outs. However, some research findings indicate that, in heavily debt driven industries, the variable of investment carries an insignificant relationship with the dividends. Fahim and Zhu. (2015) measured investment opportunities, which can also be termed as growth opportunities of the firm, by analyzing the accumulated retained earnings, and the total assets. Thus, the same approach has been adopted in this study, as the literature very strongly supports the preference of internal financing for exploiting the opportunities that exist in the market. Leverage is also another important factor that needs to be studied in detail. Literature indicates that firms that are highly leveraged, tend to have a lower level of payout, due to the heavy external financing costs and the transition costs. As a result, leveraged firms do not declare regular dividends. Moreover, the capital ratio is used to measure leverage, and represents the amount of assets on which shareholders can exercise residual claim. Moving on, the liquidity shows how quickly the assets of the company can be converted into cash, in order to fulfill its liabilities. This is applicable if, by any chance, these assets crystalize altogether. Ben Naceur, Goaied, and Belanes (2006), state that, liquid organizations are ideally supposed to have more cash, or easily convertible assets, and therefore, as a usual practice, they are in better position to issue dividends.

Keeping all these insights under consideration, the econometric equation of the logistic function is as follows, 

the Tranquil Periods?

$$
P\left(Y_{i, t}\right)=\frac{1}{1+e^{-\pi(i, t)}}
$$

A multinomial logit model that can be used in order to examine the payout policy of banks during a financial crisis, where payout policy has $j$ $=4$ alternatives, can be expressed as follows:

$$
\frac{\operatorname{Pr}[Y=m]}{\operatorname{Pr}[Y=K]}=\frac{1}{1+e^{-P i j, t}}
$$

Here, the variable $m ;(m=1, \ldots, m)$ represents all the 4 alternative choices that are made by the banks, and the variable $\mathrm{K}$ represents the reference category. Furthermore,

$$
\begin{gathered}
P_{i j, t}=\alpha+\beta_{1} P_{i, t}+\beta_{2} S_{i, t}+\beta_{3} I_{i, t}+\beta_{4} P L i_{i, t}+\beta_{5} L e_{i, t}+\beta_{6} \text { PreC }_{i, t} \\
+\beta_{7} C_{i, t}+\beta_{8} \text { PostC }_{i, t}+\varepsilon_{i, t}
\end{gathered}
$$

The dependent variable $P$, represents the 4 forms of payout policy of the banks. These policies state that, (1) the bank pays no dividend, (2) the bank pays cash dividends, (3) the bank pays stock dividend, and (4) the bank pays a mixed dividend. These outcomes are coded as $0,1,2$, and 3, respectively. The main variable of interest is the dummy variable (financial crisis; PreC, C, and PostC) which takes a value of 1, if a particular observation falls into a particular sub-period, and otherwise it is 0 . In addition to this, the control variables are selected using a framework that has been suggested by Trojanowski and Reneeboog (2005), and Case, Hardin, and $\mathrm{Wu}$ (2012). These include the P (profitability), S (size), I (investment opportunities), Li (liquidity), and the Le (leverage).

\section{Results and Discussion}

In order to carry out the empirical investigation, the data analysis is carried out in four stages; these entail the descriptive statistics, the propensity to distribute funds (analyzing the most promising payout channel), the payout trends (the size of the payout during, and across crisis) and the multinomial logit regression (to observe the various factors that can significantly affect the payout policy of the banks).

\subsection{Descriptive statistics}

Table 1 represents the summary statistics of the variables used in the empirical analysis. For the banks that have been included in the sample, the mean value of the Liquidity which primarily entails the estimated ratio of 
the advances, to the total deposits, is $90.64 \%$, with a standard deviation of $6.29 \%$. Furthermore, with respect to the firm size, a mean value of 8.33 , with a standard deviation 0.45 , indicates that, on average the commercial banks in Pakistan have a high market capitalization. Other than this, the average value of the ROA (a measure of firm profitability) is $1.06 \%$, with a deviate of $0.82 \%$, which depicts the high profitability of banks during the sample period that is taken into account. In addition to this, the findings also reveal that the average value of Investment is $1.3 \%$. Similarly, the mean value of a bank's leverage, which is $8.68 \%$, represents a very high percentage of debt in the capital structure. Lastly, the average value of the dividend payout ratio (i.e., the cash dividends only), and the total payout ratios are $24.58 \%$ and $42.74 \%$, respectively. In their entirety, the findings indicate that even though banks use stock dividends as a means of distribution, a major portion of the total payout is still covered by cash dividends.

Table 1: Summary Statistics

\begin{tabular}{lccccccc}
\hline Statistics & ROA & Liquidity & Leverage & TPO & Size & Investment & DPO \\
\hline Mean & $90.64 \%$ & 8.33 & $1.06 \%$ & $1.30 \%$ & $8.68 \%$ & $24.58 \%$ & $42.74 \%$ \\
Median & $92.02 \%$ & 8.37 & $1.04 \%$ & $1.02 \%$ & $7.14 \%$ & $17.39 \%$ & $52.11 \%$ \\
Std. Dev. & $6.29 \%$ & 0.45 & $0.82 \%$ & $18.70 \%$ & $7.32 \%$ & $49.01 \%$ & $32.58 \%$ \\
Observations & 308 & 308 & 308 & 308 & 308 & 308 & 308 \\
\hline
\end{tabular}

\subsubsection{Averages Classified according to different Sub-Sample Periods}

Table 2 reports the averages of the variables during the three different sub-periods which were identified as the pre-crisis, crisis, and the post-crisis periods. The objective was to verify the possible implications of the global financial crisis, on the different aspects that are part of the banks' operations. The results revealed that the highest average of the liquidity ratio falls within the crisis period $(90.64 \%)$, followed by the post-crisis period $(91.10 \%)$ and then finally in the pre-crisis period $(89.81 \%)$. This was an indication that the management of the banks prefer to keep more cash in hand, in order to deal with any sudden surges, or ups and downs in the crisis (Hauser, 2013). Furthermore, the average value of the Size in the precrisis period (7.88) is marginally lower than that in the crisis, and the postcrisis period ( $8.33 \& 8.6)$. These results are consistent with the expectation, that the size of the banks keep on increasing. With respect to profitability, the mean value of 0.49 , in the crisis period, is lower than the mean value in the pre and post-crisis periods (1.32 \& 1.06). Similarly, it is evident by the negative value of $-0.54 \%$ that the growth opportunities of the banks tend to squeeze at the time of the crisis. Additionally, the average value of the 

the Tranquil Periods?

Leverage is lower in the crisis, and post-crisis periods, relative to the precrisis period. Consistent with the signaling hypothesis, the mean value of both the dividend payout ratio, and the total payout ratio, is higher during the crisis period, than the other two periods. This implies that banks use dividends to convey signals in the market about their financial strength, especially during the times in which market turmoil is at its peak.

Table 2: Average Classified according to different Sub-Sample Periods.

\begin{tabular}{lcccccc}
\hline & \multicolumn{2}{c}{$\begin{array}{c}\text { Pre-Crises } \\
\mathbf{( 2 0 0 2 - 2 0 0 6 )}\end{array}$} & \multicolumn{2}{c}{$\begin{array}{c}\text { Crises } \\
\mathbf{( 2 0 0 7 - 2 0 1 0 )}\end{array}$} & \multicolumn{2}{c}{$\begin{array}{c}\text { Post-Crises } \\
\mathbf{( 2 0 1 1 - 2 0 1 5 )}\end{array}$} \\
\cline { 2 - 7 } & $\begin{array}{c}\text { Mean } \\
\mathbf{\%}\end{array}$ & $\begin{array}{c}\text { Median } \\
\mathbf{\%}\end{array}$ & $\begin{array}{c}\text { Mean } \\
\mathbf{\%}\end{array}$ & $\begin{array}{c}\text { Median } \\
\mathbf{\%}\end{array}$ & $\begin{array}{c}\text { Mean } \\
\mathbf{\%}\end{array}$ & $\begin{array}{c}\text { Median } \\
\mathbf{\%}\end{array}$ \\
\hline Liquidity & 89.81 & 92.96 & 90.64 & 92.02 & 91.10 & 92.01 \\
\hline Size & 7.88 & 7.96 & 8.33 & 8.37 & 8.6 & 8.65 \\
\hline Profitability & 1.32 & 1.3 & 0.49 & 1.23 & 1.06 & 1.04 \\
\hline Investment & 0.19 & 0.27 & $(0.54)$ & 1.12 & 3.88 & 1.35 \\
\hline Leverage & 7.04 & 5.79 & 8.42 & 7.39 & 8.68 & 7.14 \\
\hline DPO & 44.25 & 40.49 & 57.65 & 51.47 & 42.74 & 52.11 \\
\hline TPO & 19.86 & 8.90 & 24.07 & 17.39 & 29.7 & 36.97 \\
\hline
\end{tabular}

\subsubsection{Propensity to Pay (Dominant Payout Channel by Firms)}

Table 3 exhibits the decision to distribute funds, and the channel preferences of the commercial banks from the year 2002 through 2015. The findings show that the payout policy of the banks have fluctuated substantially over the given time period. The results reveal that $33.33 \%$ of the banks preferred to cut down their dividends in the year 2002. The trend of no dividend reached its minimum in the year 2007 and 2008, where only $13.33 \%$ of banks decided not to announce their dividends. Following the liquidity crisis, the banks decided, again, not to distribute funds to their shareholders. Besides this, $20 \%$ of the banks chose to pay their earnings to the investors through cash dividends in the year 2002, but this proportion decreased to $6.67 \%$ in the year 2010 , with a slight increase to $13.33 \%$ in the year 2008. After this, there was a gradual increase which went up to $60 \%$ in the year 2015, which reveals that after the crises period had passed, the banks preferred to distribute the funds by utilizing the channel of cash dividends. When shifting the focus on the stock dividends, it is evident from the table that up till the year 2003, it was not a preferable mode of payment for the banks. However, later on in the year 2004, it became the second most utilized payout channel, with a $40 \%$ weightage. Whereas, till the end of the year 2015, it again became less popular among the banks, as compared to the cash dividends. Similarly, the mixed dividend policy has 
slightly changed from the year 2002 to 2013, and has shown a gradual decrease in the year 2014. In short, our results contradict the findings of Denis and Osobov (2008), and Fama and French (2001), who claim that the number of US firms, that pay a dividend to their shareholders, substantially declined over the last quarter of a century. However, these results were consistent with the results of Floyd et al. (2015), and AlMalkawi et al. (2014).

Table 3: Propensity to Pay (Dominant Payout Channel by Banks)

\begin{tabular}{ccccc}
\hline Year & No Dividend & $\begin{array}{c}\text { Cash } \\
\text { Dividend }\end{array}$ & $\begin{array}{c}\text { Stock } \\
\text { Dividend }\end{array}$ & $\begin{array}{c}\text { Mixed } \\
\text { Dividend }\end{array}$ \\
\hline 2002 & 33.33 & 20 & 13.33 & 33.33 \\
2003 & 46.67 & N/A & N/A & 53.33 \\
2004 & 20 & 13.33 & 40 & 26.67 \\
2005 & 20 & 13.33 & 20 & 46.67 \\
2006 & 26.67 & 6.67 & 26.67 & 40 \\
2007 & 13.33 & 6.67 & 20 & 60 \\
2008 & 13.33 & 13.33 & 26.67 & 46.67 \\
2009 & 33.33 & 6.67 & 13.33 & 46.67 \\
2010 & 33.33 & 6.67 & 26.67 & 33.33 \\
2011 & 20 & 20 & 20 & 40 \\
2012 & 26.67 & 26.67 & 13.33 & 33.33 \\
2013 & 26.67 & 33.33 & 13.33 & 26.67 \\
2014 & 26.67 & 46.67 & 13.33 & 13.33 \\
2015 & 33.33 & 60 & 6.67 & N/A \\
\hline
\end{tabular}

\subsubsection{Year by Year Percentage Change in Payout Trend or Size of Payout}

Table 4 reports the average amounts spent on cash dividends, and the total payout that is made to the shareholders by commercial banks every year. As it is evident from the table that the dividend payout ratio remains volatile over the complete span of the sample period. Moreover, as expected, every increasing trend is accompanied by a decline in the subsequent year. Likewise, the total payout ratio also exhibits inconsistent behavior throughout the complete sample period that is taken into consideration. Keeping in mind the results, our findings are contradictory to DeAngelo, DeAngelo, and Stulz (2004), as they argue that, on an average, the amount spent by firms on dividends has increased over time. However, our findings lend some support to the results that were revealed by Zhou, Bhooth, and Chang (2013). 

the Tranquil Periods?

Table 4: Year by Year Percentage Change in Payout Trend or Size of Payout

\begin{tabular}{lcccc}
\hline Year & \multicolumn{2}{c}{$\begin{array}{c}\text { Dividend Payout Policy } \\
\text { Mean }\end{array}$} & \multicolumn{2}{c}{ Total Payout Policy } \\
Median & 25.56 & 37.56 & 39.57 \\
\hline $\mathbf{2 0 0 2}$ & 22.3 & 18.93 & 33.51 & 24.45 \\
$\mathbf{2 0 0 3}$ & 16.76 & 29.02 & 50.24 & 44.04 \\
$\mathbf{2 0 0 4}$ & 16.35 & 66.9 & 57.78 & 36.3 \\
$\mathbf{2 0 0 5}$ & 29.98 & 20.86 & 42.16 & 45.92 \\
$\mathbf{2 0 0 6}$ & 13.92 & 17.1 & 58.36 & 46.24 \\
$\mathbf{2 0 0 7}$ & 17.34 & 128.52 & 62.66 & 54.43 \\
$\mathbf{2 0 0 8}$ & 16.04 & 33.26 & 43.85 & 49.9 \\
$\mathbf{2 0 0 9}$ & 26.57 & 80.95 & 65.71 & 54.82 \\
$\mathbf{2 0 1 0}$ & 36.32 & 26.05 & 53.03 & 53.32 \\
$\mathbf{2 0 1 1}$ & 28.2 & 30.97 & 50.41 & 59.17 \\
$\mathbf{2 0 1 2}$ & 33.92 & 26.6 & 42.07 & 52.11 \\
$\mathbf{2 0 1 3}$ & 27.8 & 24.4 & 32.07 & 42.37 \\
$\mathbf{2 0 1 4}$ & 26.72 & 30.29 & 36.14 & 52.36 \\
$\mathbf{2 0 1 5}$ & 31.82 & & & \\
\hline
\end{tabular}

\subsection{Financial Crises and Payout Channels}

In this study, a multinomial logistic model is used to explain the likelihood of a firm, opting to distribute funds in the three different subperiods that have been defined. The Wald statistics in the pre-crisis, crisis, and the post-crisis period $(176.31,185.82, \& 188.32)$, with a P-value of 0.000 , imply that the overall model is significant in nature. To be specific, it indicates that the predictor considerably defines the log-odds of the dependent variable. Moreover, the log-likelihood in the pre-crisis is 195.0196, in the crisis, it is -190.26689 , and in the post-crisis period, it is 189.01754, which shows the probability of observing a given set of observations, given the value of the parameters that are taken into account.

\subsubsection{Payout Policy of Commercial Banks in Pre-Crises Period}

It is evident from the table 5 that in the pre-crisis period, the log odds of paying cash dividend, relative to no dividend, have increased by 0.83 , with an increase that is experienced in the profitability. These results support the findings of Carroll (1995), who documents that when the profitability increases banks prefer to distribute funds to their shareholders in the form of cash dividends. Moreover, the probability of dividend cuts is higher for leveraged banks. Contrary to the facts presented by Trojanowski and Reneeboog (2005), the results reveal that the likelihood of the dividend payment being made is positively related to the corporate investment. While 
a negative association is found between the payout policy and the firm's liquidity, the probability of paying cash dividends to no-dividend increases by 0.08 . While the likelihood of paying stock dividend, vs no-dividend increases by 0.27 . Interestingly, panel $B$ and $C$ of 5 provide some additional insights regarding the channel preferences of banks. It is documented that the size of the bank is positively associated with the probability of the earnings being distributed to the investors through the mean value of the cash dividend, rather than using the stock or the mixed dividends. Furthermore, it is noteworthy that profitable banks prefer mixed dividends over other means of distribution. However, for leveraged banks, cash dividends are the most important channel of distribution, as the odds of making the payments in the form of mixed dividends and the stock dividends decreases by -0.08 and -0.3 , respectively. When taking into consideration the increase in liquidity and investments, banks prefer to use other means of distribution rather than paying cash dividends. Lastly, the coefficient of the pre-crisis dummy indicates that banks prefer to distribute their earnings in the form of dividends (either cash or mixed), rather than retaining them in the business. 

the Tranquil Periods?

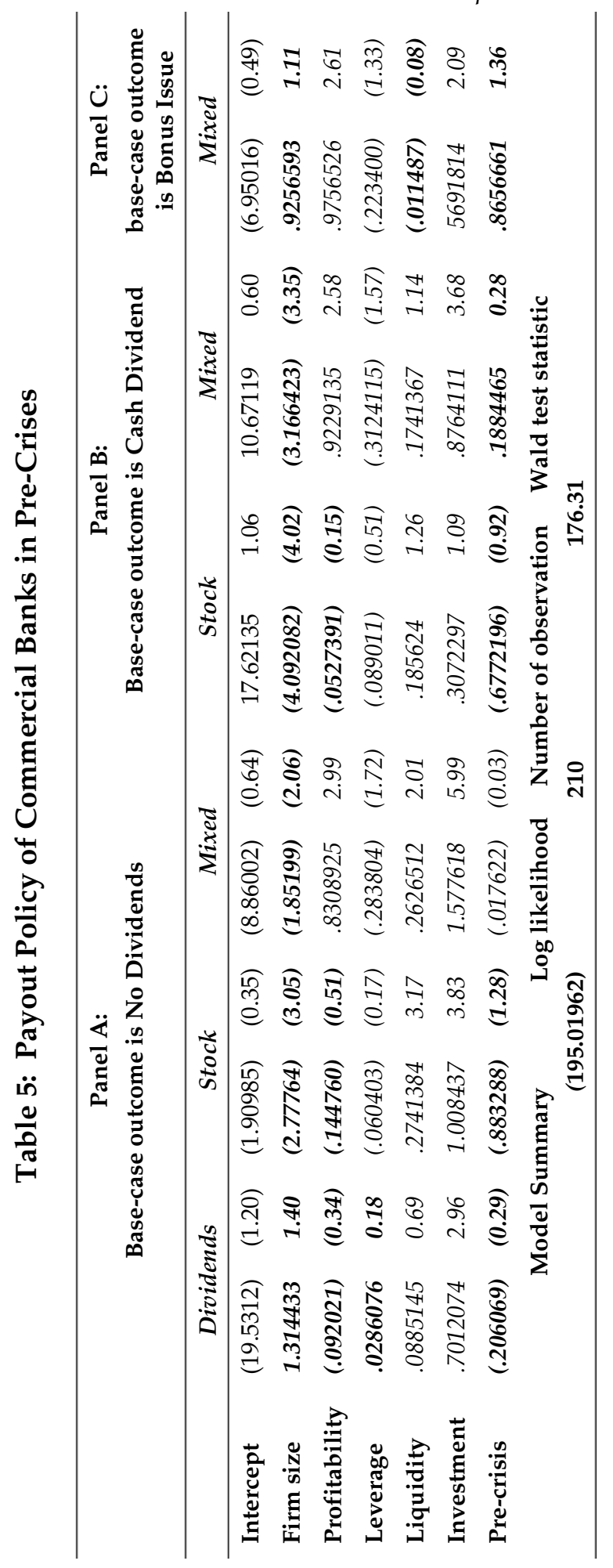




\subsubsection{Payout Policy of Commercial Banks in Crises Period}

Table 6 explains a bank's policy decision, regarding the dividend distribution to the shareholders in the crisis period. The result documents that a firm's size is positively related to the cash dividend that are paid out, as the $\log$ odds of cash dividends vs no dividends increase by a value of 1.2. In addition to this, parallel to the result of the pre-crisis, with an increase in the profits, the probability of paying mixed dividends, relative to no dividends, also increases by a value of 1.02. The paying out of mixed dividends, however, is an aggrandized strategy, over the no dividends policy for profitable banks. These observations and results appear to be in line with the findings of the previous studies (Ahmad \& Javid, 2008; Fatemi \& Bildik, 2012; Malkawi, 2008; Nissim \& Ziv, 2001). Moreover, it is also observed that a high leverage firm is less likely to be a dividend payer (Agrawal \& Jayaraman, 1994), as the log odds of paying the stock dividends and the mixed dividends, vs no dividends, also decrease by a value of 0.7 and 0.4 , respectively. As reported in the table, both the liquidity and the investment, positively affect a firm's payout decision. Similarly, panel $B$ and $C$ also reveal that, as far as the channel preferences are concerned, profitable banks often use mixed dividends as a means of distribution. The likelihood of paying a mixed dividend is higher in the case of both the cash dividend and the stock dividend. Interestingly, the variable of leverage also appears as a critical determinant of whether a cash dividend will be paid out or not. Results reveal that mixed dividends are the least promising means of distribution, as their probability relative to the cash dividends decreases by a value of -0.33 .

Moreover, as far as the time is concerned, the estimates of the dummy variable (crisis) reveal that the log odds of paying the mixed dividends, as compared to the cash dividends, and the stock dividends increased by a value of 1.65. Our findings have come out to be in line with David and Ginlinger's (2016) analysis, which reports that in crisis periods, the firms Prefer to distribute funds through the channel which entails the mixed dividends. 

the Tranquil Periods?

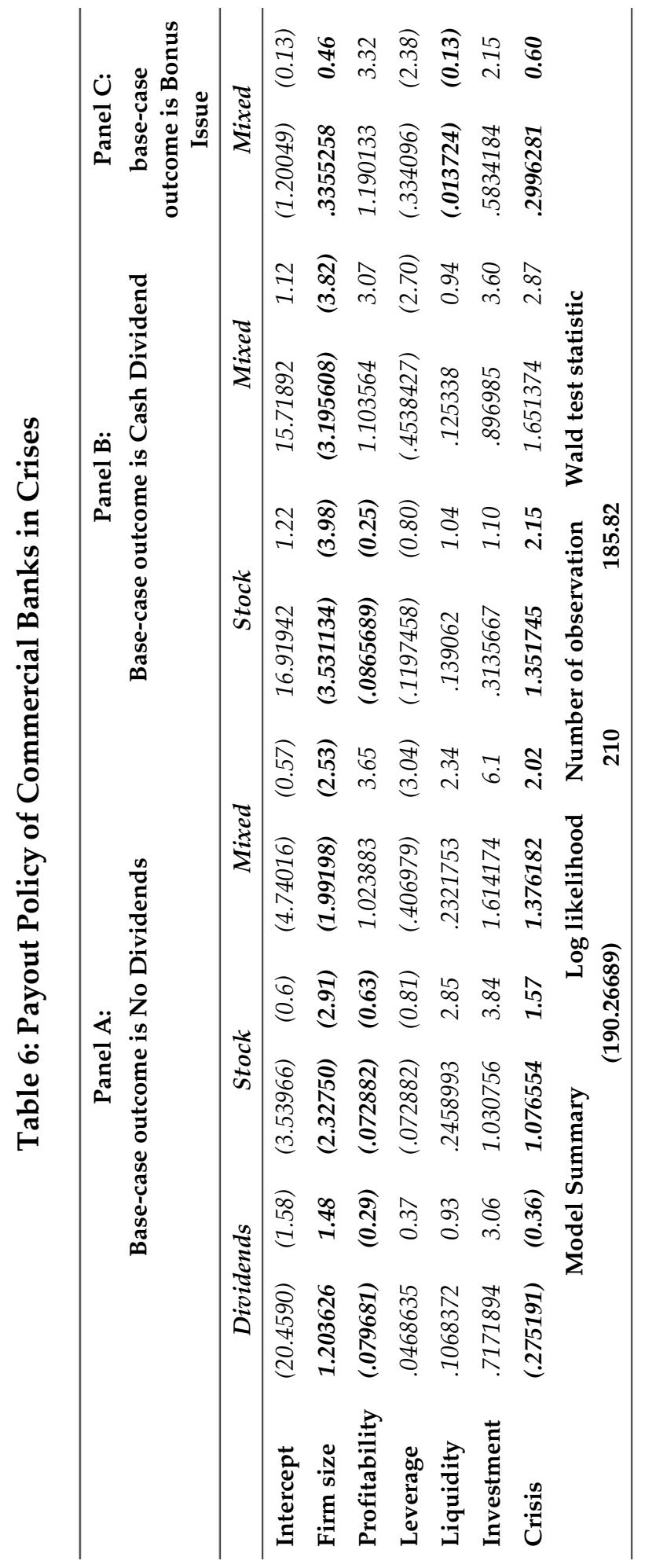




\subsubsection{Payout Policy of Commercial Banks in Post-Crises Period}

Table 7 presents the results of the multinomial logit model, which is estimated to determine the payout policy of the banks in the post-crisis period. The findings of this study show that the firm size is significantly and positively associated with the dividend policy. Similarly, with an increase in the profit, the probability of paying the cash dividends and the mixed dividends, vs no dividends, also increases by a value of 0.02 and 0.78 , respectively. However, the probability of paying a stock dividend, relative to no dividend, decreases by a value of 0.27 . Furthermore, the variable of leverage is also has a significantly negative relationship with the payout policy in the post-crisis period. As reported by Ahmad and Javid (2008), it is found that liquidity leads to an increase in the odds of declaring the cash dividends by a value of 0.036 , the stock dividends by 0.23 , and the mixed dividends by 0.26 . This is in comparison to the no dividend policy, indicating that liquid banks are more likely to be dividend payers. Similarly, investments show a positive relationship with the payout decision, as the log odds of paying cash dividends, stock dividends, and the mixed dividends, vs no dividends increases by $0.719,1.032$, and 1.544 respectively (La Porta et al., 2002). With regard to the time period that is taken under consideration, the estimates of the dummy variable (postcrisis) reveal that after the financial crisis, cash dividends are the most utilized source of payout for commercial banks.

The results of panels $B$ and $C$ demonstrate that big firms prefer cash dividends over other alternatives (i.e., the stock dividends and the mixed dividends). Interestingly, the analysis reveals that the mixed dividends are the most preferred channel of distribution for profitable banks, as the probability of paying the mixed dividends as compared to the cash dividends and the stock dividends increases by 0.78 and 1.05, respectively. While on the other hand, for highly leveraged banks, the mixed dividend is the least preferred channel, as the log odds of paying the mixed dividend vs the cash dividend, are decreased by -0.18 .

Finally, the likelihood that a bank pays cash dividends decreases, when there is an increase experienced in both the liquidity and investments.

Overall, we have found that the likelihood of receiving funds is higher for more profitable, highly liquid, and less levered banks (Fama \& French, 2001). However, in contrast to the observations made by Hauser (2013), and Reddemann et al. (2010), the global financial crisis, at different 

the Tranquil Periods?

periods of time, have had no significant impact on the payout policy of the banks. The evidence presented above resonates with the results of Floyd et al. (2015), and Al-Malkawi et al. (2014), who claim that the declining propensity to distribute funds is not evident for the banks, especially at the time when the market turmoil is at its peak. The possible justification that explains the reluctance of the banks, to cut off the dividends amidst a crisis, could entail that banks use the dividends' tool to give away signals in the market, which are meant to show the propensity of their financial strength. 


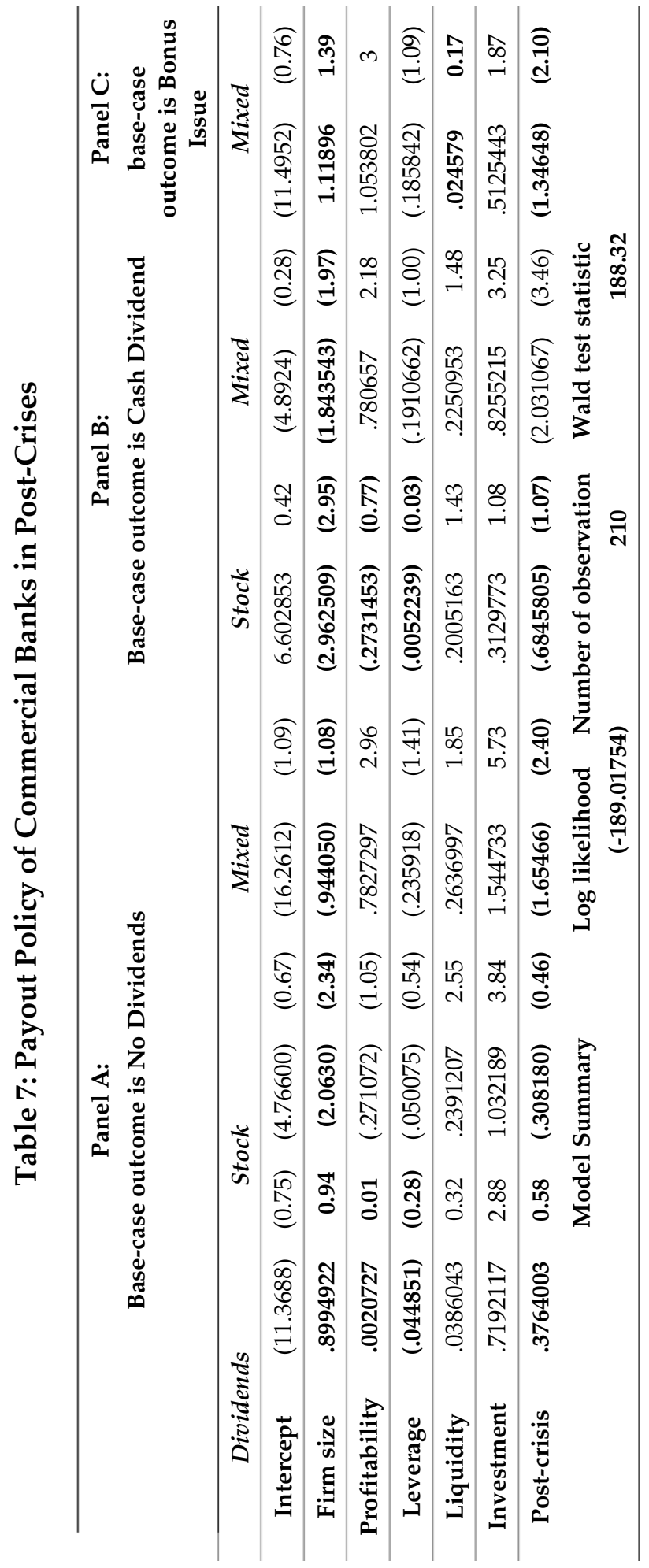



the Tranquil Periods?

\section{Policy Implications in Global Turmoil \& COVID-19 Situation}

The entire focus of this paper has been to address the key issue of how exactly financial institutions, especially commercial banks, should behave when it comes to the dividend distribution and the channel preferences, during a national or global crisis situation. Results have shown that the pay-out ratio, and the preferred distribution mode remain unaffected, despite the significant losses in the global economic system. In such cases, Pakistani banks have usually showed the willingness to distribute dividends, primarily to signal regarding their financial strength to various parties, such as depositors and creditors. Moreover, another reason to consider payout, in the times of a national or global crisis, is to keep their shareholder's confidence intact, especially when it comes to the bank's solvency during the period of financial distress. In order to deal with global financial crises in the past years, the government and the SBP undertook some key reforms in the foreign exchange, and the public debt markets. In addition to this, an aggressive macroeconomic stabilization programme, with the help of International Monetary Fund (IMF), was also initiated, so as to put the economy back on track. Due to the stringent measures taken by the government and the regulatory bodies, the global financial crises 2007-2010 only left a minor impact on the country's economy, and its financial system. Despite the level of shocks transmitted into the Pakistani economy, regulators still need to formulate flexible policies when it comes to the dividend payments and the capital requirements, so that the financial sector can be taken out of trouble, especially when it is in a state of extreme uncertainty and predicament.

Now, taking in to account the on-going global pandemic, in the context of the corporate dividends policy, there was a crises which ascended due to the outbreak of the novel Corona Virus (COVID-19) in Wuhan city of China, in December 2019. This global phenomenon has been posing as a great threat to the national health systems, and makes the world's economic system, more vulnerable. In this regard, the International Monetary Fund (IMF) recently revised its World Economic Outlook, whereby the growth of $3.3 \%$ in 2020 , eventually turned into severe economic contractions, with the global economy falling sharply by $3 \%$. Hence, in IMF's words: "This makes the Great Lockdown the worst recession since the Great Depression, and far worse than the Global Financial Crisis (GFC). Since the outbreak of the Covid-19 pandemic, authorities worldwide have taken the required measures to ensure that the banking sector can continue to lend to the real economy. For this purpose, the regulators in Pakistan should also allow the firms to use a capital buffer 
to absorb the losses. Capital distribution, whether through dividends, share buybacks or discretionary bonuses, should be restricted through supervisory action which may help the firms to support the real economy in case of a national or global crisis.

\section{Conclusion}

Researchers in corporate finance are intrigued about what the banking sector entails, mainly because of the heightened governance that it offers, its agency issues, and its significance for the well-functioning of a country's economic system. Moreover, the unique macroeconomic setting, and the regulatory shift caused by the recent global financial crisis of 20072009 have further enhanced this interest. The current study probes deeper into defining the impact of the global financial crisis on the payout policy adopted by banks in Pakistan. For the empirical investigation, a sample of commercial banks listed in the Pakistan Stock Exchange, spanning over the time period between the years of 2002-2015, has been analyzed. The multinomial logit regression model is estimated to examine the probability of a firm distributing its earnings to the shareholders, and the probability of a firm selecting a particular channel of distribution (Cash dividend, Stock dividend \& mixed dividend).

The analysis reveals that a majority of the banks (65\%) prefer to pay out their earnings in the form of dividends, rather than going for the retention strategy. Moreover, unlike other countries, the commercial banks in Pakistan do not show a diminishing propensity to distribute funds to its shareholders. As far as the preference for the particular channel is concerned, although the importance of the other means of distribution is increasing, cash dividends still cover a large part of the total payout.

We have also documented, via our findings, that the likelihood of a bank distributing its funds (as a dividend) is positively related to the firm's characteristics, such as its profitability, liquidity, and investment. While, on the other hand, it is also negatively affected by the leverage (Fama \& French, 2001). As consistently experienced in the extant literature, (Abreu \& Gulamhussen, 2013; Al-Malkawi et al., 2014; Floyd et al., 2015) the payout policy of commercial banks in Pakistan does not appear to be significantly influenced by the changes in the macroeconomic environment (pre-crisis, crisis, \& post-crisis). Interestingly, this is despite the existence of strict regulatory standards, and the argument that dividend cuts are the only way to improve financial strength. Moreover, our findings still support the rationale provided by the signaling hypothesis. Banks 

the Tranquil Periods?

distribute the pay dividends in order to signal their financial strength to various parties such as the depositors and creditors. Furthermore, they also take this route to keep their shareholder's confidence about the banks' solvency during any periods of financial distress. Overall, our results show that the commercial banks in Pakistan exhibit a reluctance to cut dividends, primarily because of the fear that investors may interpret it as a sign for future problems. Taken together, the fact presented here is consistent with the view that, in emerging countries such as Pakistan, with a weak enforcement environment, dividends may be considered as a substitute for poor shareholder protection and governance practices.

Lastly, the empirical evidence presented in this study offers useful implications for corporate finance and the corporate governance mechanism. Other than that, it will also enable investors to invest in those where the payout channel choices cater and resonate with the payout needs, and also work as a guide for policymakers while developing the regulatory reforms. 


\section{References}

Abreu, J. F., \& Gulamhussen, M. A. (2013). Dividend payouts: Evidence from US bank holding companies in the context of the financial crisis. Journal of corporate Finance, 22(September), 54-65.

Ahmed, H., \& Javid, A. Y. (2008). The determinants of dividend policy in Pakistan. Retrieved from https://mpra.ub.unimuenchen.de/ 37339/1/MPRA_paper_37339.pdf

Agrawal, A., \& Jayaraman, N. (1994). The dividend policies of all-equity firms: A direct test of the free cash flow theory. Managerial and decision economics, 15(2), 139-148.

Akbar, M., \& Baig, H. H. (2010). Reaction of Stock Prices to Dividend Announcements and Market Efficiency in Pakistan. Lahore Journal of Economics, 15(1), 103-125.

Asghar, M., Shah, S. Z. A., Hamid, K., \& Suleman, M. T. (2011). Impact of dividend policy on stock price risk: Empirical evidence from equity market of Pakistan. Far East Journal of Psychology and Business, 4(1), 45-52.

Al-Malkawi, H. A. N. (2008). Factors Influencing Corporate Dividend Decision: Evidence from Jordanian Panel Data. International Journal of Business, 13(2), 177-195.

Al-Malkawi, H. A. N., Bhatti, M. I., \& Magableh, S. I. (2014). On the dividend smoothing, signaling and the global financial crisis. Economic Modelling, 42 159-165.

Andres, C., Doumet, M., Fernau, E., \& Theissen, E. (2015). The Lintner model revisited: Dividends versus total payouts. Journal of Banking E Finance, 55, 56-69.

Basse, T. (2019). The impact of the financial crisis on the dividend policy of the European insurance industry: Additional empirical evidence. Zeitschrift für die gesamte Versicherungswissenschaft, 108(1), 3-17.

Ben Naceur, S., Goaied, M., \& Belanes, A. (2006). On the determinants and dynamics of dividend policy. International review of Finance, 6(1-2), $1-23$ 

the Tranquil Periods?

Black, F., \& Scholes, M. (1974). The effects of dividend yield and dividend policy on common stock prices and returns. Journal of Financial Economics, 1(1), 1-22.

Black, F. (1976). The pricing of commodity contracts. Journal of financial economics, 3(1-2), 167-179.Bushra, A. (2012). The determinants of corporate dividend policy in Pakistan (Doctoral thesis, Lahore School of Economics, Lahore, Pakistan.

Bushra, A., \& Mirza, N. (2015). The determinants of corporate dividend policy in Pakistan. The Lahore Journal of Economics, 20(2), 77.

Carroll, T. J. (1995). The information content of quarterly dividend changes. Journal of Accounting, Auditing E Finance, 10(2), 293-317.

Case, B., Hardin III, W. G., \& Wu, Z. (2012). REIT dividend policies and dividend announcement effects during the 2008-2009 liquidity crisis. Real Estate Economics, 40(3), 387-421.

Chen, X., Chadam, J., Jiang, L., \& Zheng, W. (2008). Convexity of the exercise boundary of the American put option on a zero dividend asset. Mathematical Finance: An International Journal of Mathematics, Statistics and Financial Economics, 18(1), 185-197.

Chen, D., Jian, M., \& Xu, M. (2009). Dividends for tunneling in a regulated economy: The case of China. Pacific-Basin Finance Journal, 17(2), 209223.

David, T., \& Ginglinger, E. (2016). When cutting dividends is not bad news: The case of optional stock dividends. Journal of Corporate Finance, 40(October), 174-191.

DeAngelo, H., \& DeAngelo, L. (1990). Dividend policy and financial distress: An empirical investigation of troubled NYSE firms. The Journal of Finance, 45(5), 1415-1431.

DeAngelo, H., \& DeAngelo, L. (2006). The irrelevance of the MM dividend irrelevance theorem. Journal of financial economics, 79(2), 293-315.

DeAngelo, H., DeAngelo, L., \& Stulz, R. (2004). Dividend policy, agency costs, and earned equity. NBER Working Papers 10599. Retrieved from https:/ / papers.ssrn.com/sol3/papers.cfm?abstract_id=563043 
Denis, D. J., \& Osobov, I. (2008). Why do firms pay dividends? International evidence on the determinants of dividend policy. Journal of Financial economics, 89(1), 62-82.

Donaldson, G. (1961). Corporate Debt Capacity. A study of corporate debt policy and the determination of corporate debt capacity (Second printing.). Division of Research, Graduate School of Business Administration, Harvard University, Boston.

Dow, J. K., \& Endersby, J. W. (2004). Multinomial probit and multinomial logit: a comparison of choice models for voting research. Electoral studies, 23(1), 107-122.

Elton, E. J., \& Gruber, M. J. (1970). Marginal stockholder tax rates and the clientele effect. The Review of Economics and Statistics, 52(1) 68-74.

Fahim, L., Khurshid, M. K., \& Tahir, H. (2015). Determinants of Dividend Payout: Evidence from Financial Sector of Pakistan. Journal of Poverty, Investment and Development, 17(1), 5-16.

Fahim, A., \& Zhu, L. (2015). Optimal investment in a dual risk model. Retrieved from https://arxiv.org/abs/1510.04924

Fama, E. F., \& French, K. R. (2001). Disappearing dividends: changing firm characteristics or lower propensity to pay? Journal of Financial economics, 60(1), 3-43.

Fatemi, A., \& Bildik, R. (2012). Yes, dividends are disappearing: Worldwide evidence. Journal of Banking \& Finance, 36(3), 662-677.

Floyd, E., Li, N., \& Skinner, D. J. (2015). Payout policy through the financial crisis: The growth of repurchases and the resilience of dividends. Journal of Financial Economics, 118(2), 299-316.

Geiler, P., \& Renneboog, L. (2016). Executive remuneration and the payout decision. Corporate Governance: An International Review, 24(1), 42-63.

Gordon, M. J. (1963). Optimal investment and financing policy. The Journal of finance, 18(2), 264-272.

Hauser, R. (2013). Did dividend policy change during the financial crisis?. Managerial Finance, 39(6), 584-606. 

the Tranquil Periods?

Hilliard, J., Jahera, J. S., \& Zhang, H. (2019). The US financial crisis and corporate dividend reactions: for better or for worse?. Review of Quantitative Finance and Accounting, 53(4), 1165-1193.

Ho, H. (2003). Dividend policies in Australia and Japan. International Advances in Economic Research, 9(2), 91-100.

Jensen, M. C., \& Meckling, W. H. (1976). Theory of the firm: Managerial behavior, agency costs and ownership structure. Journal of financial economics, 3(4), 305-360.

Khan, M. (2012). The effects of dividends on stock prices in Pakistan. International Journal of Marketing and Technology, 2(5), 231-251.

Kouser, R., Luqman, R., Yaseen, A., \& Azeem, M. (2015). Dividend payout policy and financial crisis: Evidence from the life cycle theory. Pakistan Journal of Commerce and Social Sciences (PJCSS), 9(2), 583-598.

Korkeamaki, T., Liljeblom, E., \& Pasternack, D. (2010). Tax reform and payout policy: Do shareholder clienteles or payout policy adjust?. Journal of Corporate Finance, 16(4), 572-587.

La Porta, R., Lopez-de-Silanes, F., Shleifer, A., \& Vishny, R. (2002). Investor protection and corporate valuation. The journal of finance, 57(3), 1147-1170.

Lee, C. W. J., \& Xiao, X. (2004). Tunneling dividends. Available at SSRN 693361. Retrieved from https://papers.ssrn.com/sol3/papers. cfm?abstract_id=693361

Lee, S., Singal, M., \& Kang, K. H. (2013). The corporate social responsibility-financial performance link in the US restaurant industry: Do economic conditions matter?. International Journal of Hospitality Management, 32, 2-10.

Lintner, J. (1956). Distribution of incomes of corporations among dividends, retained earnings, and taxes. The American economic review, 46(2), 97-113.

Lintner, J. (1962). Dividends, earnings, leverage, stock prices and the supply of capital to corporations. The review of Economics and Statistics, 243-269. 
Mbulawa, S., Okurut, N. F., Ntsosa, M. M., \& Sinha, N. (2020). Determinants of Corporate Dividend Policy under Hyperinflation and Dollarization by Firms in Zimbabwe. Journal of Applied Finance and Banking, 10(2), 1-24.

Miller, M., \& Modigliani, F. (1961). Dividend policy, growth, and the valuation of shares. The Journal of Business, 34(4), 411-433.

Myers, S. C., \& Majluf, N. S. (1984). Corporate financing and investment decisions when firms have information that investors do not have. Journal of financial economics, 13(2), 187-221.

Nazir, M. S., Abdullah, M. M. N., \& Nawaz, M. (2012). How dividend policy affects volatility of stock prices of financial sector firms of Pakistan. American Journal of Scientific Research, 61(61), 132-139.

Nissim, D., \& Ziv, A. (2001). Dividend changes and future profitability. The Journal of Finance, 56(6), 2111-2133.

Reddemann, S., Basse, T., \& Von Der Schulenburg, J. M. G. (2010). On the impact of the financial crisis on the dividend policy of the European insurance industry. The Geneva Papers on Risk and Insurance-Issues and Practice, 35(1), 53-62.

Trojanowski, G., \& Renneboog, L. (2005). Patterns in payout policy and payout channel choice of UK firms in the 1990s. ECGI-Finance Working Paper, (70).

Roomi, M. A., Chaudhry, N. I., \& Azeem, M. (2011). Dividend payment practices in the non-financial sector of Pakistan: empirical evidence from the Karachi Stock Exchange. Retrieved from University of Bedfordshire Repository.

Samet, M., E Jarboui, A. (2017). How does corporate social responsibility contribute to investment efficiency?. Journal of Multinational Financial Management, 40, 33-46.

Seneque, P. J. C. (1978). A Review of Factors Affecting the dividend Policy of the Firm. Investment Analysts Journal, 7(12), 8-17.

Shefrin, H. M., \& Statman, M. (1984). Explaining investor preference for cash dividends. Journal of financial economics, 13(2), 253-282. 

the Tranquil Periods?

Shepherd, C. W., \& Scott Jr, D. F. (1975). Corporate dividend policy: Some legal and financial aspects. Am. Bus. LJ, 13, 199.

Tahir, M., \& Mushtaq, M. (2016). Determinants of dividend payout: evidence from listed oil and gas companies of Pakistan. The Journal of Asian Finance, Economics and Business (JAFEB), 3(4), 25-37.

Tran, Q. T., Alphonse, P., \& Nguyen, X. M. (2017). Dividend policy: Shareholder rights and creditor rights under the impact of the global financial crisis. Economic Modelling, 64, 502-512.

Van Horne, J. C., \& McDonald, J. G. (1971). Dividend policy and new equity financing. The Journal of Finance, 26(2), 507-519.

Walter, J. E. (1963). Dividend policy: its influence on the value of the enterprise. The Journal of finance, 18(2), 280-291.

Wang, X., Manry, D., \& Wandler, S. (2011). The impact of government ownership on dividend policy in China. Advances in Accounting, 27(2), 366-372.

Zhou, J., Booth, L., \& Chang, B. (2013). Import competition and disappearing dividends. Journal of International Business Studies, 44(2), 138-154. 
